UDC 378.147.091.31-059.2

DOI: $10.31470 / 2415-3729-2019-10-143-157$

Training of the Future Vocational Education Teachers in the Conditions of Student-Centred Learning and Teaching

\title{
Taras Melnyk
}

Postgraduate student of the Pereiaslav-Khmelnytskyi

Hryhorii Skovoroda State Pedagogical University,

$\triangle$ 30, Sukhomlynskyi Str., Pereiaslav-Khmelnytskyi, Kyiv Region, Ukraine, 08401

E-mail: tapac33@gmail.com

ORCID: 0000-0001-9429-4035

\section{Iryna Dobroskok}

Doctor of Pedagogy (DSc), Professor, Head of the Vocational Education Department, Pereiaslav-Khmelnytskyi Hryhorii Skovoroda State Pedagogical University

$\triangle$ 30, Sukhomlynskyi Str., Pereiaslav-Khmelnytskyi, Kyiv Region, Ukraine, 08401

E-mail: irina.dobroskok@gmail.com

ORCID 0000-0003-0623-5145

Date of receipt of the article: September 28, 2019 Article accepted for publication: December 02, 2019

Підготовка майбутніх педагогів професійного навчання в умовах студентоцентрованого навчання і викладання

\section{Тарас Андрійович Мельник}

аспірант ДВНЗ «Переяслав-Хмельницький державний педагогічний університет імені Григорія Сковороди»,

$\triangle$ вул. Сухомлинського, 30, м. Переяслав Київська обл., Україна, 08401 


\section{Ірина Іванівна Доброскок}

доктор педагогічних наук, професор, завідувач кафедри професійної освіти, ДВНЗ «Переяслав-Хмельницький державний педагогічний університет імені Григорія Сковороди»

$\triangle$ вул. Сухомлинського, 30, м. Переяслав-Хмельницький, Київська обл., Україна, 08401

Дата надходження статті: 28 вересня 2019 р.

Стаття прийнята до друку: 02 грудня 2019 р.

\section{Abstract}

The article reveals the theoretical aspects of the future vocational education teachers' training in the conditions of student-centred learning and teaching, which is based on the principles of the flexibility of individual educational trajectories and different methods usage, students' autonomy support, mutual respect of teachers and students and the respect to the diversity of students and their needs. The purpose of the article is to highlight and analyze the peculiarities of preparation of future vocational education teachers in the conditions of studentcentred learning and teaching. In accordance with the purpose and the set objectives, such theoretical methods of research were applied as an analysis, a synthesis and the generalization of scientific-pedagogical literature and normative-legal documents. The author believes that the future vocational education teachers' training in a student-centred setting is a complex task according to the ESG recommendations. The study identifies the positive features of a student-centred approach, as well as the possible risks; characterizes and analyzes the key principles of the European Standards and Guidelines (ESG) on Quality Assurance in the European Higher Education Area (EHEA) in terms of the specificities of the training system for future vocational education teachers. Moreover, it defines that providing sufficient feedback from students, forming assessment criteria based on the creative display of acquired knowledge and skills, rational lesson planning, adherence to the "lifelong learning" principle, and promoting self-examination 
among teachers and students are the key components of implementing the student-centred learning and teaching principles. The author made a conclusion that student-centred learning and teaching contributes to the realization of intellectual, cultural and emotional potential, creates the conditions for students' self-expression and self-identification, promotes the democratic and humanistic values of institutions of higher education (IHE) as important public institutions and, having a positive impact on the quality of training, creates a springboard for realizing the educational process participants' potential on the basis of proactivity and common opinion.

Key words: future vocational education teachers, student-centred learning, student-centredness, flexible educational trajectories, ESG, democratic and humanistic values of the IHE.

\section{References}

1. European Association for Quality Assurance in Higher Education (ENQA). (2015). Standards and guidelines for quality assurance in the European Higher Education Area (ESG). Retrieved from https://enqa. eu/index.php/home/esg/ [in Ukrainian].

2. Akad. ped. nauk Ukrainy [Academy of pedagogical sciences of Ukraine] (2008). Entsyklopediia osvity - Encyclopedia of Education, 20-21.

3. Boiko, M. (2019). Studentotsenrovane navchannia v protsesi upravlinnia yakistiu profesiinoi pidhotovky maibutnoho vchytelia [Student-centred learning in the process of management of the future teacher's vocational training quality]. ScienceRise: Pedagogical Education, 4 (31), 41-45 [in Ukrainian].

4. Borodenko, S.M. (2016). Materalno-tekhnichnyi aspekt zabezpechennia studentotsentrovanoho pidkhodu v osviti [Material aspect of providing a student-centred approach in education]. 76-77 Retrieved from https://ir.kneu.edu.ua/handle/2010/29358?show=full [in Ukrainian].

5. Bratanych, A. (2017). Osoblyvosti osobystisno oriientovanoho navchannia studentiv u vyshchomu navchalnomu zakladi [Features 
of the students' personality-oriented education in higher education institution]. Osvitnii dyskurs. Humanitarni nauky - Educational discourse. Humanities, 1(1), 114-123 [in Ukrainian].

6. Dzhym, A.Yu., Baranova, S. (2017). Osobystisno-oriientovanyi pidkhid na zaniattiakh $\mathrm{z}$ inozemnoi movy [Personality-centred approach to foreign language lessons]. Molodyi vchenyi - Young scientist, 5 (45), 308-311 [in Ukrainian].

7. Dobroskok, I. (2019). Kontseptualni zasady realizatsii Smartosvity u systemi vidnosyn universytet-shkola [Conceptual foundations for the implementation of Smart-education in the system of university school relations]. Novyi Kolehium-New Collegium, 2, 42-44 [in Ukrainian].

8. Ilchenko, A. \& Podliesna, H. (2018). Shliakhy realizatsii osobystisno-oriientovanoho pidkhodu do navchannia $\mathrm{V}$ protsesi formuvannia osobystosti zdobuvacha vyshchoi osvity [Ways of implementing a personality-oriented approach to learning in the process of forming the personality of a higher education applicant]. Dyrektor shkoly, litseiu, himnazii-Headmaster of the school, lyceum, gymnasium, 6 (2), 389-400 [in Ukrainian].

9. Kovalova, K.V. (2017). Osobystisno-oriientovane navchannia, yak skladova protsesu fakhovoi pidhotovky spetsialistiv inzhenernoho profiliu [Personality-oriented studying as a component of the process of professional training of specialists of the engineering field]. Tekhnika, enerhetyka, transport APK [Engineering, energy, transportation of agroindustrial complex]. Vyp. 4, pp. 46-50 [in Ukrainian].

10. Kulaha, I. \& Tkachenko, O. (2016). Studentotsentrovanyi pidkhid yak osvitnia innovatsiia u vyshchii osviti Ukrainy [Studentcentered approach as an educational innovation in higher education in Ukraine]. International Scientific and Practical Conference "UkraineEU. Modern Technology, Business and Law», 378 [in Ukrainian].

11. Sosnytska, N. \& Hlikman, S. (2017). Studentotsentrovanyi pidkhid do profesiinoi osvity $\mathrm{v}$ umovakh staloho rozvytku suspilstv [Student-centred approach to vocational education in the context of sustainable societies development]. Naukovyi visnyk Lotnoi akademii; 
Seriia: Pedahohichni nauky - Scientific Bulletin of the Flight Academy. Pedagogical Sciences, 1, 379 [in Ukrainian].

12. Furdui, S. (2017). Studentotsentrovane navchannia yak perspektyvnyi element vyshchoi osvity [Student-centred learning as a promising element of higher education]. Tradytsii ta innovatsii $v$ suchasnii pedahohichnii diialnosti: yevropeiskyi vymir - Traditions and innovations in modern pedagogical activity: the European dimension, 126-128 [in Ukrainian].

\section{Вступ}

Переосмислення й видозміна ролі студентів в освітньому процесі $є$ відображенням зародження чергового витка історії педагогіки вищої школи. Ще не так давно - 20-25 років тому викладач вважався беззаперечним джерелом істини, вербальна трансляція якої і біля його основним завданням. Наразі ж, з появою в освіті інформаційно-комунікаційних технологій (IKT) i SMARTзасобів, основним інструментом взаємодії яких $є$ Інтернет, ролі викладача та студента суттєво зазнали суттєвих змін: тепер вони працюють в одній команді, утворюючи щось на кшталт освітньої синергіï.

Документ під назвою Стандарти і рекомендації щодо забезпечення якості в Свропейському просторі вищої освіти, більш відомий під скороченням ESG, в п. 1.3 чітко регламентує наступне: «Заклади повинні забезпечити реалізацію програм таким чином, щоб заохотити студентів брати активну роль у розвитку освітнього процесу, а оцінювання студентів відображало цей підхід» (ESG, 2015: 11). Продиктовані вимогою часу зміни безперечно знаходять своє відображення і в освітній підготовці майбутніх педагогів професійного навчання, що й зумовлює актуальність дослідження за даним напрямом.

Дослідження й наукові розвідки щодо проблеми підготовки фахівців вищої школи представлені в таких вітчизняних вчених: I. Зязюн, В. Кремень, В. Андрущенко та інші (концептуальні засади філософії освіти); Н. Ничкало, В. Луговий, В. Радкевич, та 
інші (підготовка майбутніх педагогів професійного навчання) Б. Свтух, В. Лозова, О. Пехота, І. Доброскок та інші (аспекти підготовки фахівців у закладах вищої освіти) I. Бех, І. Якиманська, О. Бондаревська, Л. Качалова, В. Бочелюк та інших (теоретикометодологічні аспекти реалізації особистісно-орієнтованого навчання). Та незважаючи на значну кількість психологопедагогічних досліджень даної проблеми, ми схильні вважати, що саме теоретико-методологічні аспекти підготовки майбутніх педагогів професійного навчання в умовах студентоцентрованого навчання і викладання вивчені недостатньою мірою, що й обумовлює актуальність публікації.

Мета статті - висвітлити та проаналізувати особливості підготовки майбутніх педагогів професійного навчання в умовах студентоцентрованого навчання і викладання.

\section{Матеріал і методи досліджень}

Відповідно до мети та поставлених завдань були застосовані теоретичні методи дослідження: аналіз, синтез і узагальнення науково-педагогічної літератури та нормативно-правових документів.

\section{Результати та їх обговорення}

Студентоцентрований підхід, як зазначає М. Бойко, характеризується зміщенням акцентів в ході навчання 3 викладання на навчання, в якому студент стає ключовою фігурою, бере участь в управлінні ЗВО та власною професійною підготовкою, виступаючи при цьому повноцінним суб'єктом відносин (М. Бойко, 2019: 42). Реалізація студентоцентризму зумовлює максимальне наближення освіти, навчання і виховання студентства у відповідності до їхніх здібностей та життєвих планів (Сосницька, Глікман, 2017: 379). Студентоцентроване навчання - це насамперед ідея реалізації максимального потенціалу студентів задля отримання конкурентного статусу на ринку праці, адже саме за таких умов будуть задовольнятись потреби й очікування як студентів, так і роботодавців Однак студентоцентроване навчання - це не лише заняття. В позааудиторний час студенти також мають ряд додатко- 
вих потреб й інтересів, наприклад, потребу у відвідуванні спортивних секцій. Для цього та багатьох інших напрямків розвитку 3 ВО повинен створити належні умови (Кулага, Ткаченко, 2017: 379).

Досить часто в науково-педагогічній літературі обабіч терміну «студентоцентроване навчання» зустрічається й раніше розповсюджений термін «особистісно-орієнтоване навчання». О.Савченко стверджує, що особистісно-орієнтоване навчання - це, перш за все, форма організації навчання на засадах урахування індивідуальних потреб і можливостей, а також поваги до його особистості (Академія пед. наук, 2008: 20-21).

Проведення занять 3 урахуванням принципів особистісноорієнтованого навчання передбачає не лише передачу знань від викладача до студентів, а й застосуваннями ними навичок в наближених до реальності ситуаціях, що уособлює собою практичну важливість навчання (Джим, Баранова, 2017:30).

А. Братанич акцентує на тому, що актуальність такого підходу визначається запитом з боку суспільства у підвищенні рівня особисто-орієнтованого аспекту виховання студентів. Також дослідник вважає, що освітнє середовище ЗВО має ціннісні орієнтації та загальну спрямованість як фундамент його поведінки та життєдіяльності (Братанич, 2017:117). Можливість пліч-о-пліч 3 викладачем торувати шлях до практично-орієнтованих знань, вмінь і навичок є вдалим способом забезпечення автономності майбутнього педагога професійного навчання, оскільки тепер з'являється місце для дискусії. А застосування дискусії, диспуту - круглих столів, симпозіумів, дебатів - $є$ також доцільним в ході реалізації особисто-орієнтованого підходу (Ільченко, Подлєсна, 2018:398). Досить часто в особисто-орієнтованому навчанні реалізовується й метод проектів, який передбачає самостійну роботу студентів (індивідуальну, в парах, в групах), формуючи їх суб'єктний досвід (Ковальова, 2017: 48).

Можемо виділити наступні фундаментальні положення ESG щодо студентоцентрованого навчання і викладання, які варто розглянути більш детально: 
- повага і врахування різноманітності студентів та їх потреб, уможливлення гнучких навчальних траєкторій;

- врахування та використання різних способів надання освітніх послуг, якщо це доцільно;

- гнучкість використання різноманітних педагогічних методів;

- регулярне оцінювання та коригування способів надання освітніх послуг і педагогічних методів;

- підтримка відчуття автономності у того, хто навчається, водночас забезпечуючи відповідний супровід і підтримку з боку викладача;

- сприяння взаємній повазі у стосунках «студент-викладач» (ESG, 2015: 12).

Згідно нашого бачення, гнучкість навчальної траєкторії багато в чому може стати визначальним чинником мотивації й прагнення студента до здобуття знань, вмінь та навичок. Обумовлюється це тим, що всі студенти є різними: світогляд, бекграунд, амбіції та середовище спілкування та інші аспекти формування індивіда роблять їх кардинально відмінними між собою. Як наголошує I. Доброскок, орієнтація на інтереси особистості, що відповідають тенденціям розвитку сучасного суспільства та ринку праці наразі $\epsilon$ пріоритетним завданням в освіті (Доброскок, 2019:42). Керуватись в даному випадку потрібно не лише щирими намірами й повагою до студентів, а й чутливістю, розумінням психології і когнітивних процесів студентів, таких як сприйняття, формування понять, пам'ять, уява, логіка та підходи до вирішення завдань (Фурдуй, 2017:127).

Гнучкість використання різноманітних педагогічних методів може демонструватись лише за умови, що викладач в ході ретельної підготовки до заняття послуговується не лише виключним прагненням наблизити показник засвоюваності матеріалу до максимально можливого, а й шукає способи реалізувати це за допомогою тих інструментів, засобів і гаджетів, які є близькими до реального (позааудиторного) життя студента, і тому суттєво підвищуватимуть інтерес до освітнього процесу. Завдяки цьому навчання 3 якоїсь 
відокремленої специфічної діяльності поступово перетворюватиметься в органічну складову існування, невід’ємну умову підтримки власної конкурентоспроможності, а отже, й матеріального благополуччя. Використання роздрукованого навчального матеріалу, без сумніву, є простішим варіантом, однак в умовах діджиталізації таке рішення не знайде відгуку з боку студентів. В той же час можливість ознайомлюватися 3 напрацюваннями викладача 3 екранів власних смартфонів, реалізовуючи концепцію Bring Your Own Device (BYOD) стане вдалим відображенням розумного наближення навчання до ритму життя молоді. Однак це потребує наявності відповідної матеріально-технічної бази конкретного ЗВО. В розумінні С. Бороденко, відсутність належної матеріальнотехнічної бази та матеріального стимулювання професорськовикладацького складу перетворить спробу реалізації студентоцентрованого підходу на явище суто декларативного характеру, що не нестиме за собою якісних змін у результатах освітнього процесу студентів (Бороденко, 2016:76).

Викладач, що за умов студентоцентризму перетворюється на рівноправного партнера в ході освітнього процесу, повинен змінити ставлення як до своїх обов'язків та ролей, так і до самого себе. Перш за все, це стосується готовності до адекватного сприйняття критики на свою адресу: студенти набагато краще розуміються на сучасних інформаційних технологіях, швидше опрацьовують великі обсяги даних, потребують менше часу на освоєння навичок роботи з новим прикладним і програмним забезпеченням. I як наслідок, суттєво переважаючи над викладачами, досить часто справедливо нарікають на їхній обскурантизм. Тому досить важливо, аби викладачі навчились правильно реагувати на подібні зауваження, долучаючись до ІТ-спільнот в соціальних мережах, де можна було б дізнатися більше про сучасні технології, а також постійно спонукати студентів до надання зворотного зв'язку. Постійний різноплановий зворотній зв'язок створить відкрите навчальне середовище, в якому викладач буде не лише навчати, а й навчатися. Наприклад, створення Google-форм може стати цінним 
інструментом взаємодії. В ній студенти могли б більш детально описати потенціал певних додатків для смартфону використання яких було б корисним і цікавим, способи раціоналізації витрат часу за допомогою нестандартних форм подачі навчального матеріалу, або ж надсилання посилання на корисні статті про підходи та методи вивчення конкретної дисципліни в закордонних ЗВО. Періодичний самоаналіз викладачем власних досягнень теж може позитивним чином впливати на провадження студентоцентризму в ході підготовки майбутніх педагогів професійного навчання, адже тепер на зміну запитанню «Наскільки професійно та сумлінно я виконую свої посадові обов'язки?» приходить «Чи допоміг мій професіоналізм та сумлінне ставлення до посадових обов'язків допомогти студентам реалізувати свої освітні потреби та потенціал?».

Підтримка автономності студента в системі підготовки майбутніх педагогів професійного навчання формує в студентах такі риси як сумлінність, самодисципліна, вміння ефективно керувати власним часом, брати на себе відповідальність та демонструвати освітню ініціативу. Як підсумок, студенти стають більш свідомими й готовими до подальшої професійної самореалізації. Вкрай важко уявити високоефективне навчальне середовище й без взаємної поваги між студентами та викладачами. Кожен 3 них є однаково важливим представником освітньої екосистеми: без педагогів освітній процес є неможливим, в той час як без студентів він позбавлений сенсу. Саме тому усвідомлення взаємної цінності один одного виступає рушійною силою інституційних змін в освіті вищої школи, як на рівні розуміння мотивів, так і спільного бачення досягнення кращих результатів.

3 метою успішної реалізації принципів студентоцентрованого навчання викладачі в ході підготовки майбутніх педагогів професійного навчання повинні акцентувати увагу на наступних аспектах своєї професійної діяльності:

- забезпечення достатньої кількості аудиторного часу та поза аудиторних можливостей для зворотного зв'язку: періодичне 
проведення анонімних опитувань щодо якості роботи викладача, створення відповідних Google-форм, створення рейтингу викладачів кафедри;

- важливість планування заняття: виділення часу на можливі запитання й відповіді, хронометраж блоків заняття, орієнтовний розподіл студентів за категоріями зацікавленості, уважності, ініціативності;

- реалізація принципу «навчання протягом в життя» в ході підготовки до занять: постійне відслідковування тенденцій в галузі IT (моніторинг ринку навчального програмного забезпечення, перегляд відео-уроків по застосуванню IKT та SMART засобів);

- популяризація практики самоаналізу серед викладачів та студентів з метою відслідковування динаміки змін та прогресу;

- формування критеріїв оцінювання результатів навчання не на основі заучування матеріалу, а творчого прояву здобутих знань, вмінь, навичок на практиці.

Однак, на нашу думку, студентоцентризму притаманні й деякі суперечності. Користь студентоцентризму як базового ціннісного орієнтиру в освіті багато в чому залежить від сумлінного ставлення студентів до навчання та свідомості їхнього вибору майбутньої професії. Досить складним завданням є формування індивідуальної освітньої траєкторії для студента, який не володіє цілісним баченням своїх професійних та життєвих перспектив. І хоча виховання й ціннісно-моральна підготовка до життя також є складовими навчання, вирішальна роль у визначенні пріоритетних напрямів розвитку лишається за здобувачем вищої освіти. Ще одним можливим негативним фактором студентоцентризму в ході підготовки майбутніх педагогів професійного навчання ми можемо виокремити ризик привілейованого ставлення до окремо взятих студентів, або ж навпаки - це ставлення в силу невдалих особистісних взаємин може бути заангажованим. Скажімо, привілейоване ставлення може бути обумовлене наданням освітніх послуг різними, більш цікавими та простити способами, а заангажованість й відверта байдужість може 
трактуватись викладачем як «підтримка відчуття автономності студента». Механізми уникнення та профілактики подібних проявів повинні бути чітко визначеними в межах освітньої програми.

\section{Висновки}

Зміна вектору традиційної вітчизняної освітньої парадигми на користь цінностей передових європейських країн $є$ важким кроком, що супроводжується кризовим станом якості вищої освіти. Однак невідворотність цих змін $є$ очевидною, і усвідомлення проблемності функціонування існуючої системи $є$ першим кроком до іiі успішного реформування. Підготовка майбутніх педагогів професійного навчання в умовах студентоцентризму є складним комплексним завданням, передбаченим рекомендаціями ESG. Студентоцентроване навчання i викладання сприяє реалізації інтелектуального, культурного та емоційного потенціалу, створенню умов для самовираження та становлення власної ідентичності студентів, а також розвиває демократичні та гуманістичні цінності ЗВО як важливих суспільних інституцій. Саме тому студентоцентроване навчання і викладання позитивним чином впливає на якість підготовки та створює плацдарм для реалізації потенціалу учасників освітнього процесу на основі проактивності та спільному баченню.

Проблема підготовки майбутніх педагогів професійного навчання в умовах студентоцентрованого навчання i викладання потребує подальших наукових розвідок в напрямку розробки відповідної методології та пошуків оптимальних рішень щодо забезпечення матеріально-технічної бази вітчизняних ЗВО.

\section{Література}

1. European Association for Quality Assurance in Higher Education (ENQA). Standards and guidelines for quality assurance in the European Higher Education Area (ESG). 2015. C. 12. URL: https:/enqa.eu/index.php/home/esg/ (Дата звернення 13.09.2019).

2. Акад. пед. наук України. Енцииклопедія освіти. 2008. С. 20-21. 
3. Бойко М. Студентоценроване навчання в процесі управління якістю професійної підготовки майбутнього вчителя. ScienceRise: Pedagogical Education. 2019. Вип. 4 (31), 41-45.

4. Бороденко C.M. Матерально-технічний аспект забезпечення студентоцентрованого підходу в освіті. 2016. С. 76-77. URL: https://ir.kneu.edu.ua/handle/2010/29358?show=full (Дата звернення 10.09.2019).

5. Братанич А. Особливості особистісно орієнтованого навчання студентів у вищому навчальному закладі. Освітній дискурс. Гуманітарні науки. 2017. 1(1), С.114-123.

6. Джим А.Ю., Баранова С. Особистісно-орієнтований підхід на заняттях з іноземної мови. Молодий вчений. 2017. Вип.5 (45), 308-311.

7. Доброскок I. Концептуальні засади реалізації Smart-освіти у системі відносин університет - школа. Новий Колегіум. 2019. № 2, C. 42-44.

8. Ільченко А., Подлєсна Г. Шляхи реалізації особистісноорієнтованого підходу до навчання в процесі формування особистості здобувача вищої освіти. Директор школи, ліцеюю, гімназї. 2018. №6(2). С. 389-400.

9. Ковальова К.В. Особистісно-орієнтоване навчання, як складова процесу фахової підготовки спеціалістів інженерного профілю. Техніка, енергетика, транспорт АПК. 2017. Вип. 4, С. 46-50.

10. Кулага I., Ткаченко О. Студентоцентрований підхід як освітня інновація у вищій освіті України. Тези доповідей Другої міжнародної науко-практичної конференції «Ukraine - EU. Modern Technology, Business and Law». 2016. 378 C.

11. Сосницька Н., Глікман С. Студентоцентрований підхід до професійної освіти в умовах сталого розвитку суспільств. Науковий вісник Льотної академї; Серія: Педагогічні науки. 2017. Вип. 1, С.379.

12. Фурдуй С. Студентоцентроване навчання як перспективний елемент вищої освіти. Традищї та інноващії в сучасній 
педагогічній діяльності: європейський вимір: збірник наукових праць за матеріалами науково-практичної конференції. 2017. С. 126-128.

\section{Мельник Т.А., Доброскок I.I.}

\section{Підготовка майбутніх педагогів професійного навчання в умо- вах студентоцентрованого навчання і викладання}

\section{Анотація}

У статті досліджені теоретичні аспекти підготовки майбутніх педагогів професійного навчання в умовах студентоцентрованого навчання і викладання, що грунтується на засадах гнучкості індивідуальних навчальних траєкторій, підтримки відчуття автономності студентів, взаємоповаги викладачів та студентів, гнучкості використання різноманітних педагогічних методів та поваги до різноманітності студентів і їхніх потреб. В ході дослідження було виявлено позитивні риси впровадження студентоцентрованого підходу, а також можливі ризики щодо цього. Були охарактеризовані й проаналізовані ключові принципи Стандартів і рекомендацій щодо забезпечення якості в Свропейському просторі вищої освіти (ESG) у розрізі до особливостей системи підготовки майбутніх педагогів професійного навчання. 3'ясовано, що забезпечення достатньою мірою зворотного зв'язку від студентів, формування критеріїв оцінювання на основі творчого прояву набутих знань, вмінь та навичок, раціональне планування занять, дотримання принципу «навчання протягом життя» та популяризація практики самоаналізу серед викладачів та студентів є ключовими складовими реалізації принципів студентоцентрованого навчання і викладання.

Ключові слова: майбутні педагоги професійного навчання, студентоцентроване навчання, студентоцентризм, гнучкі освітні траєкторії, ESG, демократичні та гуманістичні цінності ЗBO. 
Мельник Т.А., Доброскок И.И.

\section{Подготовка будущих педагогов профессионального обучения в условиях студентоцентрованого обучения и преподавания}

\section{Аннотация}

В статье исследованы теоретические аспекты подготовки будущих педагогов профессионального обучения в условиях студентоцентрованого обучения и преподавания, основанной на принципах гибкости индивидуальных учебных траекторий, поддержки ощущение автономности студентов, взаимоуважения преподавателей и студентов, гибкости использования различных педагогических методов и уважения к разнообразию студентов и их потребностей. В ходе исследования было выявлено положительные черты внедрения студентоцентрованого подхода, а также возможные риски по этому поводу. Были охарактеризованы и проанализированы ключевые принципы стандартов и рекомендаций по обеспечению качества в Европейском пространстве высшего образования (ESG) в разрезе с особенностями системы подготовки будущих педагогов профессионального обучения. Установлено, что обеспечение достаточной степени обратной связи от студентов, формирование критериев оценки на основе творческого проявления приобретенных знаний, умений и навыков, рациональное планирование занятий, соблюдение принципа «обучение в течение жизни» и популяризация практики самоанализа среди преподавателей и студентов являются ключевыми составляющими реализации принципов студентоцентрованого обучения и преподавания.

Ключевые слова: будущие педагоги профессионального обучения, студентоцентроване обучения, студентоцентризм, гибкие образовательные траектории, ESG, демократические и гуманистические ценности ЗВО. 